\title{
Vitamin D receptor Apal polymorphism associated with progression of liver disease in Vietnamese patients chronically infected with hepatitis $B$ virus
}

\author{
Nghiem Xuan $\operatorname{Hoan}^{1,2,3,4^{*}+}$ (D), Nguyen Khuyen ${ }^{5+}$, Dao Phuong Giang ${ }^{3,6 \dagger}$, Mai Thanh Binh ${ }^{3,7}$, Nguyen Linh Toan ${ }^{4,8}$, \\ Do Tuan Anh ${ }^{9}$, Ngo Tat Trung ${ }^{2,6}$, Mai Hong Bang ${ }^{2,4,7}$, Christian G. Meyer ${ }^{3,4,10}$, Thirumalaisamy P. Velavan ${ }^{3,4,10 \dagger}$ and \\ Le Huu Song ${ }^{1,2,4^{*}+}$
}

\begin{abstract}
Background: Vitamin D derivatives and their receptor (VDR) are potent modulators of immune responses in various diseases including malignancies as well as in metabolic and infectious disorders. The impact of vitamin D receptor polymorphisms on clinical outcomes of hepatitis B virus (HBV) infection is not well understood. This study aims to investigate the potential role of VDR polymorphisms (Taql, Fokl, Apal, and Bsml) in Vietnamese HBV infected patients and to correlate these polymorphisms with the progression of HBV-related liver disease.

Methods: Four hundred forty-three HBV infected patients of the three clinically well-defined subgroups chronic hepatitis B (CHB, $n=183)$, liver cirrhosis $(\mathrm{LC}, n=89)$ and hepatocellular carcinoma (HCC, $n=171)$ and 238 healthy individuals $(H C)$ were enrolled. VDR polymorphisms were genotyped by DNA sequencing and in-house validated ARMS assays. Logistic regression models were applied in order to determine the association of VDR polymorphisms with manifest HBV infection as well as with progression of related liver diseases mulin different genetic models.

Results: The VDR Apal CA genotype was less frequent in HCC than in CHB patients in different genetic models (codominant model, $\mathrm{OR}=0.5,95 \% \mathrm{Cl}=0.3-0.84, P=0.004$; dominant model, $\mathrm{OR}=0.46,95 \% \mathrm{Cl}=0.27-0.76, P=$ 0.0023). In the recessive model, the genotype Apal AA was found more frequently among HCC compared to CHB patients $(\mathrm{OR}=2.56,95 \% \mathrm{Cl}=1.01-6.48, P=0.04)$. Similarly, the Apal CA genotype was less frequent in HCC than in non-HCC group codominant model, $\mathrm{OR}=0.6,95 \% \mathrm{Cl}=0.4-0.98$, dominant model, $P=0.04$ and $\mathrm{OR}=0.6,95 \% \mathrm{Cl}=$ 0.38-0.90, $P=0.017$ ). The Apal genotypes CA and AA was significantly associated with higher levels of liver enzymes, bilirubin, and HBV DNA $(P<0.05)$. No association between Taql, Fokl and Bsml polymorphisms and any clinical outcome as well as liver disease progression was found.
\end{abstract}

Conclusions: Among the four investigated VDR polymorphisms, Apal is associated with clinical outcome and liver disease progression in Vietnamese HBV infected patients.

Keywords: HBV, Hepatitis B, VDR, Polymorphism, Liver diseases

\footnotetext{
*Correspondence: nghiemxuanhoan@gmail.com; lehuusong@108-icid.com

Nghiem Xuan Hoan, Nguyen Khuyen, Dao Phuong Giang are equal

contributors.

${ }^{\dagger}$ Mai Hong Bang, Thirumalaisamy P Velavan and Le Huu Song are shared

senior authorship.

'Institute of Clinical Infectious Diseases, 108 Institute of Clinical Medical and

Pharmaceutical Sciences, 108 Military Central Hospital, Tran Hung Dao Street

N1, Hai Ba Trung District, Hanoi, Vietnam

Full list of author information is available at the end of the article
}

(c) The Author(s). 2019 Open Access This article is distributed under the terms of the Creative Commons Attribution 4.0 International License (http://creativecommons.org/licenses/by/4.0/), which permits unrestricted use, distribution, and reproduction in any medium, provided you give appropriate credit to the original author(s) and the source, provide a link to the Creative Commons license, and indicate if changes were made. The Creative Commons Public Domain Dedication waiver (http://creativecommons.org/publicdomain/zero/1.0/) applies to the data made available in this article, unless otherwise stated. 


\section{Background}

Hepatitis B virus (HBV) infection remains a major health problem even with a high coverage of effective vaccination meanwhile achieved. The infection can be lifethreatening due to its frequent severe complications, consisting of fulminant acute hepatitis, acute or chronic hepatitis (CHB), liver cirrhosis (LC) and hepatocellular carcinoma (HCC) [1]. The prevalence of HBV infections in Vietnam is high, ranging from 10 to $20 \%$ in the general population [2]. As a foreseeable result, the longterm consequences of $\mathrm{HBV}$ infection will constitute a huge burden for Vietnamese economic conditions and the health system in the next decades.

Interactions between host immune responses and HBV determine the clinical manifestations of the infection. Compelling evidence indicates that vitamin D signaling and VDR variants have a significant implication on susceptibility to HBV infection and subsequent liver diseases. In addition to its function in regulating calcium and bone homeostasis, various non-skeletal effects of vitamin D have been identified, including anti-inflammatory, antifibrotic and anti-tumor properties. The effects of vitamin $\mathrm{D}$ deficiency on various health conditions such as autoimmune diseases, malignancies and a plethora of infectious diseases have extensively been discussed [3-6]. Among communicable diseases, vitamin $\mathrm{D}$ deficiency is frequently observed in patients with hepatitis $B$ and $C$ ( $\mathrm{HCV}$ )-related liver diseases and linked to unfavorable clinical outcomes as well as poor response to antiviral treatment in chronic hepatitis B [7-10] and chronic hepatitis C [11-13].

The active form of vitamin $\mathrm{D}$ (calcitriol, 1,25(OH)2D) can modulate both innate and adaptive immune responses through binding to the vitamin D receptor (VDR) [1417]. The VDR is a member of the nuclear receptor family of transcription factors [18], which is particularly expressed on macrophages, $\mathrm{T}$ cells, and B cells $[14,15$, 19], but also in more than 30 other types of tissues [20]. It has been suggested that Vitamin D-VDR signaling regulates the expression of more than 900 genes involved in a wide array of physiological functions [17]. Therefore, VDR is considered a powerful modulator of pathophysiological mechanisms in several human diseases such as cancers, metabolic disorders and infectious diseases, including viral hepatitis [6, 11, 21-25].

The VDR gene consists of eight exons (exon 2-9) encoding the VDR structural component and six alternatively spliced untranslated exons (1a-1f) [26]. Among numerous single nucleotide polymorphisms (SNPs) identified in the $V D R$ gene, the four common variants FokI G/A (rs2228570, exon 2), BsmI C/T (rs1544410, intron 8), ApaI $\mathrm{A} / \mathrm{C}$ (rs7975232, intron 8) and TaqI T/C (rs731236, exon 9) have been examined in many studies in different ethnic groups in order to identify associations of these variants with HBV infection and liver disease outcomes [27-34]. However, the results were inconsistent. Our study in Vietnamese patients chronically infected with HBV aimed to investigate the association of these $V D R$ polymorphisms with susceptibility to $\mathrm{HBV}$ infection and liver disease outcomes.

\section{Methods \\ Patient population}

Four hundred forty-three Vietnamese HBV-infected patients were enrolled for this case-control study at the 108 Military Central Hospital, Hanoi, Vietnam, between 2012 and 2014. HBV patients were assigned to the different clinical subgroups based on clinical manifestations. Briefly, CHB patients $(n=183)$ were characterized based upon clinical symptoms such as fatigue, anorexia, jaundice, hepatomegaly, hard density of the liver, splenomegaly, hyperbilirubinemia, elevated levels of AST and ALT and HBsAg positivity for more than 6 months. HBV-infected LC patients $(n=89)$ presented clinical manifestations such as anorexia, nausea, vomiting, malaise, weight loss, abdominal distress, jaundice, edema, cutaneous arterial spider angiomas, ascites, shrunken liver, splenomegaly, hyperbilirubinemia, elevated levels of AST and ALT, prolonged serum prothrombin time, and decreased serum albumin. HCC patients $(n=171)$ were diagnosed based on the combination of clinical manifestations, imaging modalities (abdominal ultrasound, MRI, CT scanner), and histological diagnoses. None of the patients had a history of alcohol or drug abuse. In addition, 238 healthy HBsAg-negative individuals were randomly enrolled from the hospital's blood bank as controls (HC group). They were students in the universities or employers in manufacturing companies located within or nearby Hanoi. None of the HCs had a history of a liver disease, nor were they immunosuppressed. All participants were negative for anti-HCV and anti-HIV antibodies by using commercial ELISA assays (Diagnostic automation/Cortez Diagnostics, Inc., Woodland Hills, California, USA). Patients were assigned to three subgroups based on their clinical manifestations and laboratory evaluations as previously described [7] including CHB $(n=183)$, LC $(n=89)$, and HCC patients $(n=171)$. All patients and controls came from Northern Vietnam and belonged to the Kinh ethnicity. Biomedical measurements (ALT and AST enzyme levels, alpha fetoprotein (AFP), platelet count (PLT), total and direct bilirubin, albumin, prothrombin, and HBV DNA loads) were collected from medical records for each patient. Total vitamin D levels were also measured in serum samples from patients and controls using a commercial ELISA kit (Gentaur, Kampenhout, Belgium) according to the manufacturer's instructions. In addition, Peripheral blood was collected from all study subjects, and plasma 
was immediately separated. Samples were stored at $80^{\circ} \mathrm{C}$ until further use.

\section{Genotyping of VDR polymorphisms by sequencing and amplification-refractory mutation system (ARMS-PCR)}

The VDR variants TaqI, FokI, ApaI, BsmI were genotyped by direct sequencing and validated by amplificationrefractory mutation system (ARMS) methods. First, a set of 244 samples (194 HBV patients, $50 \mathrm{HCs}$ ) were genotyped for 4 SNPs. Subsequently, 96 samples out of these 244 samples that had all genotypes of each SNP were chosen for validation by ARMS-PCR. The genotyping results of the 96 samples generated through the ARMS PCR assay were completely matched against the results of direct sequencing. After validation, the remaining samples of 249 HBV patients and 199 HCs were genotyped by applying our validated ARMS PCR assay, which is a low-cost genotyping technique and suitable for common laboratory settings in Vietnam.

\section{Sanger sequencing approach}

Genomic DNA was isolated from whole blood using a DNA purification kit (Qiagen, Hilden, Germany). Four different fragments, consisting of recognized VDR variants were amplified by PCR. The primer sequences are given in Table 1. PCR amplification was carried out in a $25 \mu \mathrm{l}$ volume containing $1 \mathrm{X}$ PCR buffer, $0.2 \mathrm{mM}$ dNTPs,
$1 \mathrm{mM} \mathrm{MgCl} 2,0.15 \mathrm{mM}$ of each primer, 1 unit of Taq polymerase and $50 \mathrm{ng}$ of genomic DNA. Cycling conditions were denaturation at $95{ }^{\circ} \mathrm{C}$ for $5 \mathrm{~min}$, followed by 40 cycles of three-step cycling with denaturation $\left(94{ }^{\circ} \mathrm{C}\right.$, $30 \mathrm{~s}$ ), annealing for $35 \mathrm{~s}$ (annealing temperature for each primer pair given in Table 1), extension $\left(72{ }^{\circ} \mathrm{C}, 45 \mathrm{~s}\right)$ and a final extension step $\left(72^{\circ} \mathrm{C}, 7 \mathrm{~min}\right)$. PCR products were purified by Exo-SAP-IT (USB, Affymetrix, USA) and $5 \mu \mathrm{l}$ of products were used as sequencing templates (BigDye terminator v.1.1 cycle sequencing kit, ABI 3130XL DNA sequencer; Applied Biosystems, Foster City, USA). Determination of genotype was performed using the Geneious software (https://www.geneious.com/).

\section{Amplification refractory mutation system (ARMS) PCR assay} ARMS is a PCR application in which DNA is amplified by allele specific primers. Heterozygosity or homozygosity is differentiated by using ARMS primers (inner primers) for the mutant/polymorphic and the normal (wild type) alleles. The primer sequences and the principles of ARMS assay are listed in Table 1 and Fig. 1, respectively. After the PCR assay, the mixtures of products were resolved by $1 \%$ agarose gel electrophoresis. This procedure reliably allowed to determine individual genotypes based on the sizes of amplicons (Fig. 1) and by sanger sequencing (Fig. 2).

Table 1 Primers used for ARMS assays and DNA sequencing to genotype four VDR polymorphisms

\begin{tabular}{|c|c|c|}
\hline SNPS & Sequences & Genotype-based product size \\
\hline \multicolumn{3}{|c|}{ Taql (rs731236) } \\
\hline \multirow[t]{2}{*}{ Outer ${ }^{\$}$} & F: 5' GCT GCC GTT GAG TGT CTG TGT GGG TG 3' & \\
\hline & R: 5' ACA AGG GGC GTT AGC TTC ATG CTG CAC TC 3' & Tा: 415 and 300 bp \\
\hline \multirow[t]{2}{*}{ Inner } & T/F: 5' CAG GAC GCC GCG CTG CTT 3' & TC: 415,300 and $150 \mathrm{bp}$ \\
\hline & C/R: 5' CGG TCC TGG ATG GCC GCG 3' & CC: 415 and $150 \mathrm{bp}$ \\
\hline \multicolumn{3}{|c|}{ Bsml (rs1544410) } \\
\hline \multirow[t]{2}{*}{ Outer } & F: 5' GTG GTG TGT GGA CGC TGA GGT G 3' & \\
\hline & R: 5' TTC CTT GAG CCT CCA GTC CAG GAA AG 3' & Tा: 458 and $350 \mathrm{bp}$ \\
\hline \multirow[t]{2}{*}{ Inner } & T/F: 5' GGG CCA CAG ACA GGC CTA CA 3' & TC: 458,350 and $150 \mathrm{bp}$ \\
\hline & C/R 5' CAG AGC CTG AGT ATT GGG AAC GC 3' & CC: 458 and $150 \mathrm{bp}$ \\
\hline \multicolumn{3}{|c|}{ Apal (rs7975232) } \\
\hline \multirow[t]{2}{*}{ Outer } & F: 5' ATG GAA GGA CCT AGG TCT GGA TCC TAA ATG C 3' & \\
\hline & R: 5' GCT GCA CTC AGG CTG GAA GGA G 3' & Tा: 420 and $280 \mathrm{bp}$ \\
\hline \multirow[t]{2}{*}{ Inner } & T/F: 5' GTG GTG GGA TTG AGC AGT GAA GT 3' & GT: 420,280 and $180 \mathrm{bp}$ \\
\hline & G/R: 5' ACA GGA GCT CTC AGC TGG ACC 3' & GG: 420 and $180 \mathrm{bp}$ \\
\hline \multicolumn{3}{|c|}{ Fokl (rs2228570) } \\
\hline \multirow[t]{2}{*}{ Outer } & F: 5' ATG CCC ACC CTT GCT GAG CTC 3' & \\
\hline & R: 5' ATC TGG AGC TGA GAG GAG GGA AAA GAA GA 3' & GG: 477 and $360 \mathrm{bp}$ \\
\hline \multirow[t]{2}{*}{ Inner } & G/F: 5' GCC TGC TTG CTG TTC TTA CAG GAA C 3' & GA: 477, 360 and $160 \mathrm{bp}$ \\
\hline & A/R: 5' CTG GCC GCC ATT GCC TTC A 3' & AA: 477 and $160 \mathrm{bp}$ \\
\hline
\end{tabular}




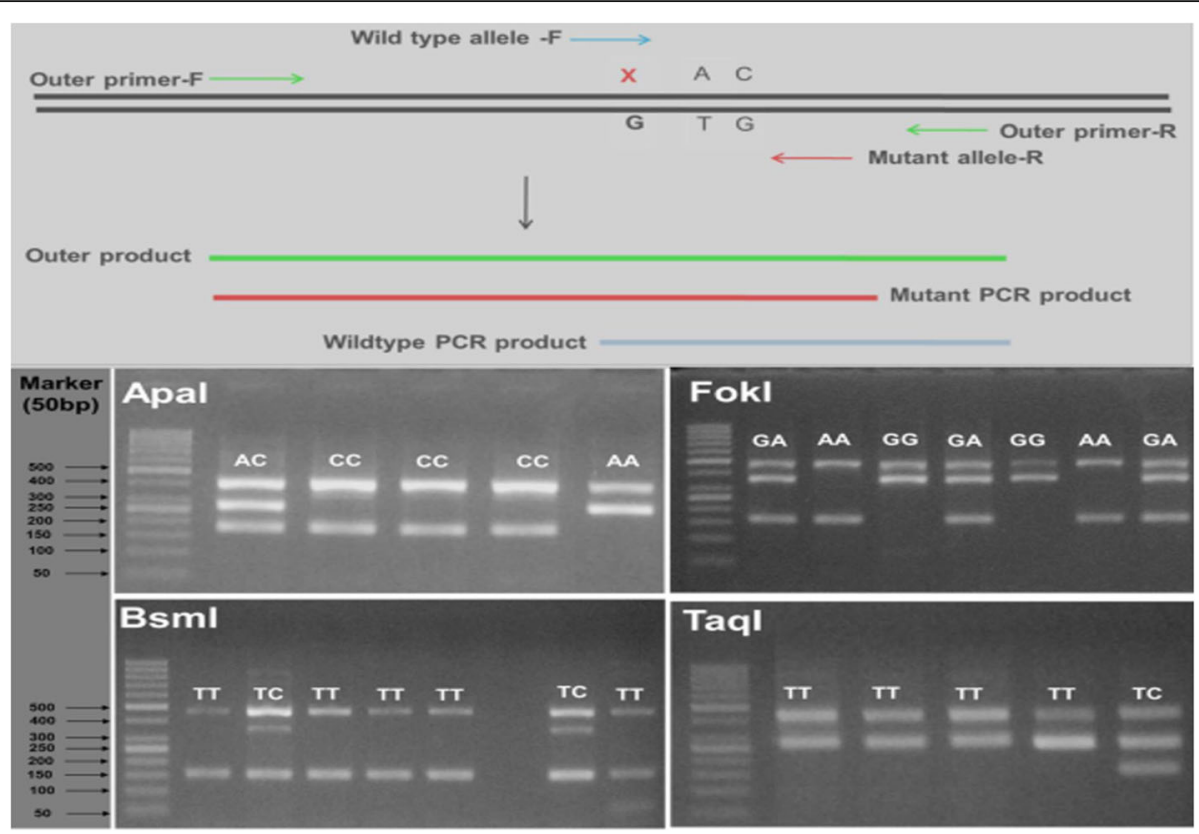

Fig. 1 Illustration of ARMS assay for analyzing VDR polymorphisms. Upper panel: Schematic diagram of the principle of ARMS to detect mutant and wildtype alleles using allele specific primers. Lower panel: Gel electrophoresis analyses to distinguish genotypes of each VDR polymorphism. (i) Apal polymorphism: AA genotype: 2 bands, 420 and 280 bp; CC genotype: 2 bands, 420 and 180 bp; AC genotype: 3 bands, 420,280 and 180 bp. (ii) Fokl polymorphism: GG genotype: 2 bands, 477 and 360 bp; AA genotype: 2 bands, 477 and 160 bp; GA genotype: 3 bands, 477,360 and 160 bp. (iii) Bsml polymorphism: TT genotype: 2 bands, 458 and 150 bp; TC genotype: 3 bands, 458,350 and 150 bp. (iv) Taql polymorphism: $\Pi$ genotype: 2 bands, 415 and 300 bp; TC genotype: 3 bands, 415, 300 and 150 bp

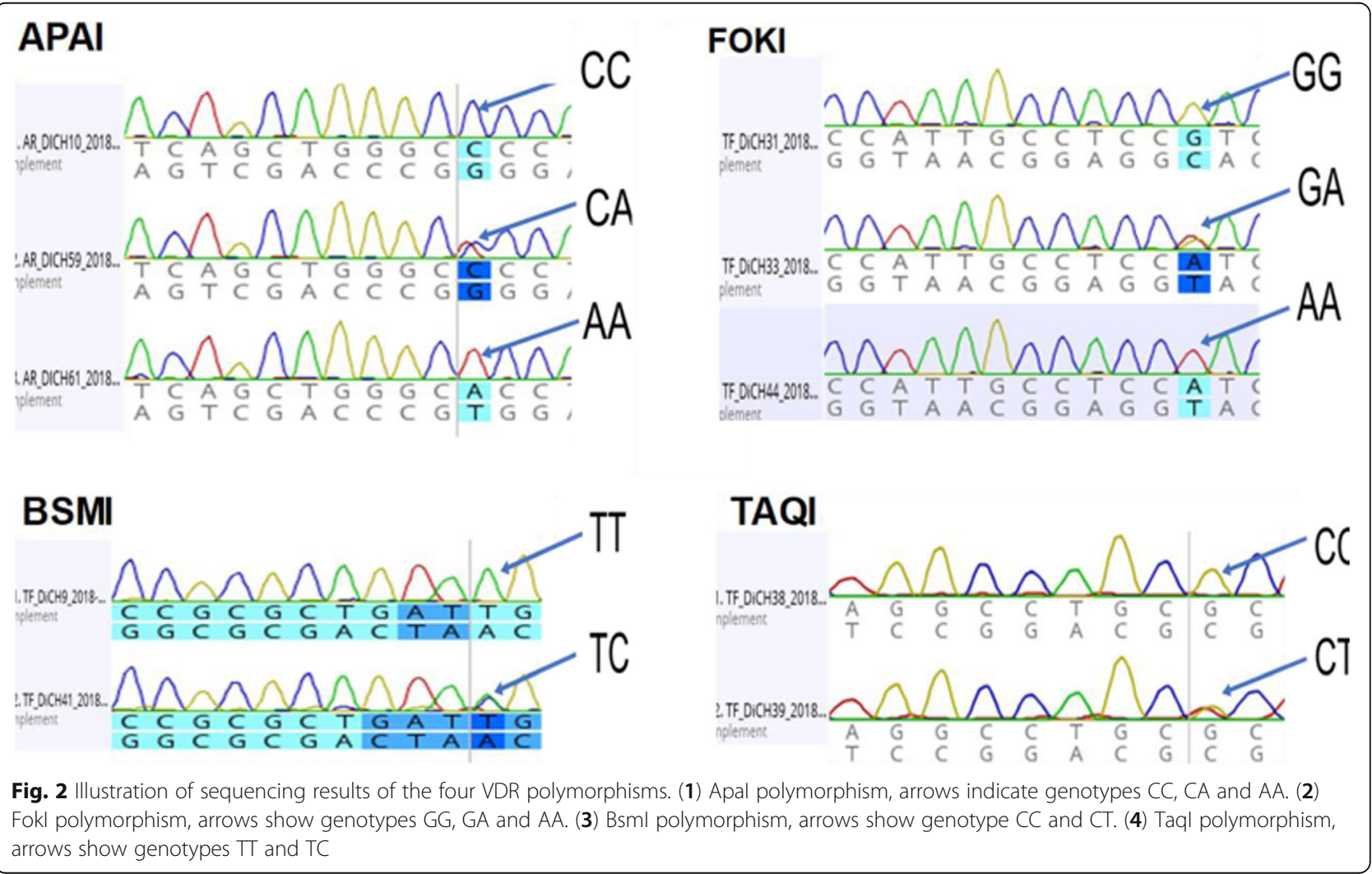




\section{Statistical and genetic analysis}

Statistical analyses were performed using $\mathrm{R}$ version 3.1.2 (http://www.r-project.org). Genotype and allele frequencies were determined by simple gene counting. Deviations from Hardy-Weinberg equilibrium were calculated for each group. Chi-square, Kruskal-Wallis and Mann-Whitney-Wilcoxon tests were used to compare differences between groups for qualitative or quantitative variables where appropriate. For genetic analyses, we used univariate analyses, and a multivariate logistic regression model adjusted for age and gender to test for associations between $V D R$ variants and HBV-related liver diseases, applying different genetic models (codominant, dominant, recessive and overdominant models). The level of significance was set at $P<0.05$.

\section{Results}

\section{Baseline characteristics of patients and controls}

The baseline characteristics of the 473 HBV-infected patients and $238 \mathrm{HCs}$ are given in Table 2 and Fig. 3. The majority of patients and HCs were males (89 and $67 \%$, respectively). HCs were younger than patients. Liver enzyme levels (ALT and AST) were higher in patients with CHB compared to those with LC and HCC $(P<0.0001)$. Patients with LC had significantly lower levels of red blood cell, platelet, albumin and prothrombin but higher levels of bilirubin compared to those without LC $(P<0.0001)$. AFP levels were significantly higher among the $\mathrm{HCC}$ group compared to the $\mathrm{CHB}$ and LC groups $(P<0.0001)$. There was no significant difference in HBV DNA levels between patient subgroups.

Vitamin D levels were measured randomly in 50 healthy individuals and in $286 \mathrm{HBV}$ patients $(\mathrm{CHB}=92$, $\mathrm{LC}=89, \mathrm{HCC}=105)$. The levels of vitamin $\mathrm{D}$ were lower in HBV patients compared to healthy individuals, but the difference did not reach statistical significance $(P>$ 0.05). However, in the patient group, vitamin D levels were significantly decreased according to progression of liver disease as found higher in $\mathrm{CHB}$ patients, followed by the LC and HCC groups (Fig. 3).

\section{VDR genotyping and the association of VDR polymorphisms with HBV infection and the progression of liver diseases}

The genotype and allele frequencies of four SNPs in the $V D R$ gene of the $473 \mathrm{HBV}$-infected patients and 238 $\mathrm{HCs}$ and the comparisons between the different patient groups are shown in Table 3. The genotype frequencies of the SNPs among HBV patients and HCs were in Hardy-Weinberg equilibrium $(P>0.05)$. In order to analyze the association of VDR SNPs with susceptibility to HBV infection, we compared the genotype frequencies between HBV patients and HCs. There were no differences in genotype frequencies between the two groups, indicating that TaqI, FokI, ApaI, BsmI are not associated with HBV infection per se.

Table 2 Clinical profiles of HBV-infected patients and healthy controls

\begin{tabular}{|c|c|c|}
\hline Clinical characteristics & Patients $(n=473)$ & Controls $(n=238)$ \\
\hline Age (years) & $51(18-90)$ & $30(18-55)$ \\
\hline Male/Female & $420 / 53$ & $159 / 79$ \\
\hline $\mathrm{HBsAg}$ & Positive & Negative \\
\hline Anti-HCV & Negative & Negative \\
\hline Anti-HIV & Negative & Negative \\
\hline AFP (IU/mL) & $11.78(0.8-400)$ & $<5$ \\
\hline HBV DNA (copies/mL) & $269,408(100-11,300,000,000)$ & NA \\
\hline $\mathrm{WBC}\left(\times 10^{3} / \mathrm{mL}\right)$ & $6.4(1.8-20.5)$ & NR \\
\hline $\mathrm{RBC}\left(\times 10^{6} / \mathrm{mL}\right)$ & $4.1(1.9-7.43)$ & NR \\
\hline $\operatorname{PLT}\left(\times 10^{3} / \mathrm{mL}\right)$ & $157(6.7-641)$ & NR \\
\hline AST (IU/mL) & $90(16-7700)$ & NR \\
\hline $\mathrm{ALT}(\mathrm{IU} / \mathrm{mL})$ & $61.25(4-4908)$ & NR \\
\hline Total Bilirubin (umol/mL) & $20.7(5.7-733)$ & NR \\
\hline Direct Bilirubin (umol/mL) & $6.7(1-450)$ & NR \\
\hline Albumin $(g / L)$ & $38.7(16-54)$ & ND \\
\hline Prothrombin (\% of standard) & $85(14-267)$ & ND \\
\hline Vitamin D levels (ng/ml) & $20.42(6.4-64.4)$ & $20(11.6-85.6)$ \\
\hline
\end{tabular}

PLT platelets, AST and ALT aspartate and alanine amino transferase, WBC white blood cells, RBC red blood cells, IU international unit, NR normal range, NA not applicable, $N D$ not done. Values given are medians and ranges 


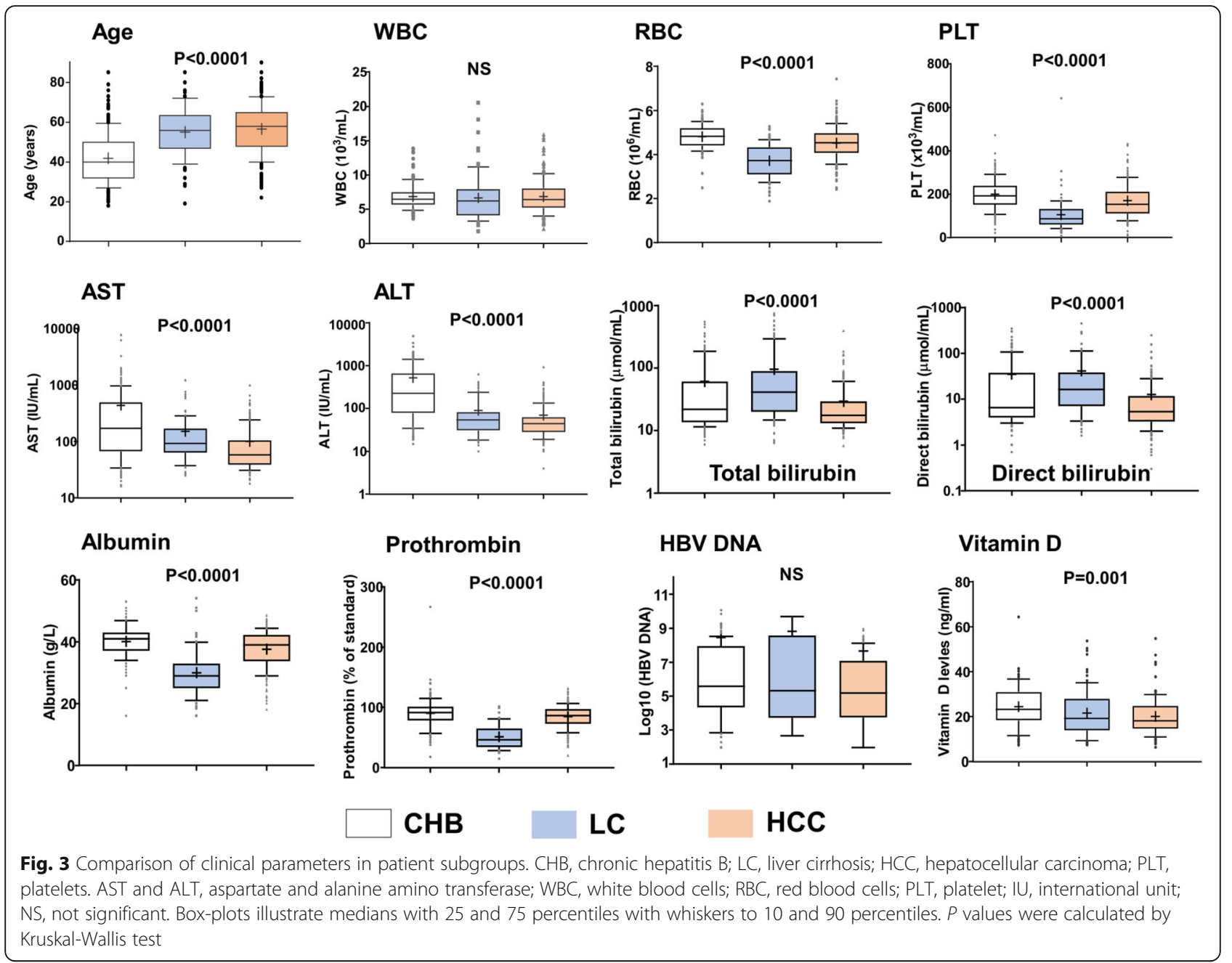

Chi-squared tests were applied to examine whether there were differences in genotype and allele frequencies of each $V D R$ polymorphism in pairwise comparisons [cases vs. HCs; HCC vs. LC; LC vs. CHB; HCC vs. CHB and $\mathrm{HCC}$ vs. non- $\mathrm{HCC}$ (or $\mathrm{CHB}+\mathrm{LC}$ )]. We found a significant difference in genotype frequencies of the ApaI polymorphism between the $\mathrm{CHB}$ and the $\mathrm{HCC}$ groups and between $\mathrm{HCC}$ and non-HCC groups $(P=0.002$ and 0.013 , respectively, Table 3 ). No associations were observed for other comparisons and for TaqI, BsmI and FokI polymorphisms.

Next, we applied logistic regression analyses for different genetic models to compare the genotype frequencies of the ApaI variant between the $\mathrm{CHB}$ and HCC groups. Genotype CA was less frequent in $\mathrm{HCC}$, compared to $\mathrm{CHB}$ patients in codominant and overdominant models (codominant model, $\mathrm{OR}=0.5,95 \% \mathrm{CI}=0.3-0.84$, adjusted $P=0.004$; overdominant model, $\mathrm{OR}=0.46,95 \% \mathrm{CI}=0.27-$ 0.76 , adjusted $P=0.0023$, Table 4). In the recessive model, the genotype AA was significantly more frequent in HCC compared to $\mathrm{CHB}$ patients $(\mathrm{OR}=2.56,95 \% \mathrm{CI}=1.01-6.48$,
$P=0.04)$. Conversely, in the dominant model, genotypes $\mathrm{CA}$ and $\mathrm{AA}$ were less frequent in $\mathrm{HCC}$ than in $\mathrm{CHB}$ patients $(\mathrm{OR}=0.62,95 \% \mathrm{CI}=0.37-0.94, P=0.04)$ (Table 4). When genotype frequencies of the ApaI variant were compared between HCC and non-HCC groups, the genotype CA was less frequent in $\mathrm{HCC}$ compared to non- $\mathrm{HCC}$ patients in codominant model $(P=0.04$, Table 4$)$.

\section{Association of VDR variants with clinical parameters}

In order to study the influence of $V D R$ variants on the clinical outcome of HBV-related liver diseases we compared laboratory parameters among HBV-infected patients with different genotypes of each of the $V D R$ variants. Pathological liver function as indicated by high levels of AST, ALT, total and direct bilirubin were observed rather in HBV patients carrying the genotypes ApaI CA or AA than in those with the genotype ApaI CC $(P<0.05)$ (Fig. 4). HBV DNA levels were significantly lower in patients with the genotype ApaI CC compared to those with either ApaI CA or AA $(P=0.0104)$ (Fig. 4). Platelet counts, albumin and prothrombin levels were lower in 
Table 3 Distribution of genotype and allele frequencies of VDR variants in controls, cases and patient subgroups

\begin{tabular}{|c|c|c|c|c|c|c|c|c|c|c|c|c|c|}
\hline \multirow{2}{*}{$\begin{array}{l}\text { VDR polymorphisms } \\
\text { Apal (rs7975232) }\end{array}$} & \multicolumn{6}{|c|}{$\begin{array}{l}\text { Genotype frequency } \\
n,(\%)\end{array}$} & \multirow[t]{2}{*}{$P^{*}$} & \multicolumn{4}{|c|}{$\begin{array}{l}\text { Allele frequency } \\
\mathrm{n},(\%)\end{array}$} & \multirow[t]{2}{*}{$P^{*}$} & \multirow[t]{2}{*}{ Comparisons } \\
\hline & CC & & $A C$ & & AA & & & $C$ & & $A$ & & & \\
\hline Controls & 114 & $(48.7)$ & 106 & $(45.3)$ & 14 & (6) & NS & 334 & (71.4) & 134 & (28.6) & NS & Cases vs. controls \\
\hline Cases & 203 & $(47.8)$ & 183 & $(43.2)$ & 38 & (9) & & 589 & (70) & 259 & (30) & & \\
\hline $\mathrm{CHB}$ & 76 & $(42.2)$ & 94 & $(52.2)$ & 10 & (5.6) & NS & 246 & (68.3) & 114 & (31.7) & NS & LC vs. CHB \\
\hline LC & 41 & $(50.6)$ & 32 & $(39.5)$ & 8 & (9.9) & NS & 114 & $(70.3)$ & 48 & (29.7) & NS & HCC vs. LC \\
\hline $\mathrm{HCC}$ & 86 & $(52.8)$ & 57 & (35) & 20 & (12.3) & 0.0022 & 229 & $(70.2)$ & 97 & (29.8) & NS & HCC vs. CHB \\
\hline non-HCC & 117 & $(44.8)$ & 126 & $(48.3)$ & 18 & $(6.9)$ & 0.013 & 360 & (69) & 162 & (31) & NS & HCC vs. Non-HCC \\
\hline Fokl (rs2228570) & GG & & GA & & AA & & & G & & A & & & \\
\hline Controls & 49 & (23) & 116 & $(54.5)$ & 48 & (22.5) & NS & 214 & $(50.2)$ & 212 & (49.8) & NS & Cases vs. controls \\
\hline Cases & 108 & $(25)$ & 233 & $(54)$ & 91 & (21) & & 449 & (52) & 415 & (48) & & \\
\hline $\mathrm{CHB}$ & 49 & $(27.8)$ & 91 & $(51.7)$ & 36 & (20.5) & NS & 189 & (53.7) & 163 & $(46.3)$ & NS & LC vs. CHB \\
\hline LC & 12 & $(15.4)$ & 47 & $(60.3)$ & 19 & (24.3) & NS & 71 & $(45.5)$ & 85 & (55.5) & NS & HCC vs. LC \\
\hline $\mathrm{HCC}$ & 47 & $(26.4)$ & 95 & $(53.4)$ & 36 & $(20.2)$ & NS & 189 & (53) & 167 & (47) & NS & HCC vs. CHB \\
\hline non-HCC & 61 & (24) & 138 & $(54.3)$ & 55 & $(21.7)$ & NS & 260 & $(51.2)$ & 248 & $(48.8)$ & NS & HCC vs. Non-HCC \\
\hline Taql (rs731236) & $\pi$ & & $\mathrm{TC}$ & & CC & & & T & & C & & & \\
\hline Controls & 177 & $(90.8)$ & 18 & $(9.2)$ & 0 & (0) & NS & 372 & (95.4) & 18 & (4.6) & NS & Cases vs. controls \\
\hline Cases & 423 & $(91.4)$ & 40 & (8.6) & 0 & (0) & & 886 & $(95.7)$ & 40 & $(4.3)$ & & \\
\hline $\mathrm{CHB}$ & 168 & $(92.3)$ & 14 & $(7.7)$ & 0 & (0) & NS & 350 & (96.2) & 14 & (3.8) & NS & LC vs. CHB \\
\hline LC & 81 & $(91.1)$ & 8 & (8.9) & 0 & (0) & NS & 170 & (95.5) & 8 & $(4.5)$ & NS & HCC vs. LC \\
\hline $\mathrm{HCC}$ & 174 & $(90.6)$ & 18 & (9.4) & 0 & (0) & NS & 366 & $(95.4)$ & 18 & (4.6) & NS & HCC vs. CHB \\
\hline non-HCC & 249 & $(91.9)$ & 22 & $(8.1)$ & 0 & (0) & NS & 520 & (96) & 22 & (4) & NS & HCC vs. Non-HCC \\
\hline Bsml (rs1544410) & CC & & $\mathrm{CT}$ & & $\pi$ & & & C & & T & & & \\
\hline Controls & 196 & $(92.5)$ & 16 & $(7.5)$ & 0 & (0) & NS & 408 & $(96.2)$ & 16 & (3.8) & NS & Cases vs. controls \\
\hline Cases & 404 & (94) & 26 & $(6.0)$ & 0 & (0) & & 838 & (97) & 26 & (3) & & \\
\hline $\mathrm{CHB}$ & 162 & $(92.6)$ & 13 & $(7.4)$ & 0 & (0) & NS & 337 & $(96.3)$ & 13 & (3.7) & NS & LC vs. CHB \\
\hline LC & 71 & $(93.4)$ & 5 & (6.6) & 0 & (0) & NS & 147 & $(96.7)$ & 5 & (3.3) & NS & HCC vs. LC \\
\hline $\mathrm{HCC}$ & 171 & $(95.6)$ & 8 & $(4.4)$ & 0 & (0) & NS & 350 & $(97.7)$ & 8 & (2.3) & NS & HCC vs. CHB \\
\hline non-HCC & 233 & (92.8) & 18 & $(7.2)$ & 0 & (0) & NS & 484 & $(96.4)$ & 18 & (3.6) & NS & HCC vs. Non-HCC \\
\hline
\end{tabular}

CHB chronic hepatitis B, LC liver cirrhosis, $H C C$ hepatocellular carcinoma; Cases $=$ all HBV infected patients; non-HCC, $\mathrm{CHB}+\mathrm{LC}, \mathrm{n}=$ number of chromosomes; OR adjusted Odds Ratio, NS not significant, $\left(^{*}\right)$ Chi squared test

patients with VDR ApaI CC compared to those with $V D R$ ApaI CA or AA. The difference was, however, not statistically significant (data not shown).

When we compared the association of the ApaI variant with laboratory parameters in the subgroups of HBV patients, we found that AST and ALT levels were lower in individuals with the genotype $\mathrm{CC}$ than in those with genotypes $\mathrm{CA}$ and $\mathrm{AA}$ among the $\mathrm{CHB}$ patients $(P=0.048$ and 0.054 , respectively). Total bilirubin and direct bilirubin levels were significantly higher in LC patients with ApaI CA or AA compared to those with the genotype $\mathrm{CC}(P=0.027$ and 0.037 , respectively) (Fig. 5). No differences were observed when comparing the occurrence of BsmI, TaqI, and FokI variants with any clinical parameter in HBV patients and in the subgroups (data not shown).

\section{Correlation between VDR variants with serum vitamin D levels}

We analyzed the association of four $V D R$ variants with the serum levels of vitamin D in all HBV patients as well as in each subgroup. We did not observe associations of any of the $V D R$ variants with vitamin D levels (data not shown).

\section{Discussion}

Vitamin D plays a crucial role in the metabolism of calcium and bone homeostasis, but has also multiple properties in the regulation of immune responses through engagement with the VDR, a member of the nuclear receptor family of transcription factors expressed on many immune cells and other tissues [14, 15, 19]. Vitamin DVDR signaling is involved in pathophysiological 
Table 4 Association of Apal variant with liver disease progression

\begin{tabular}{|c|c|c|c|c|c|c|c|c|c|c|}
\hline \multirow[t]{2}{*}{ Apal SNP } & \multicolumn{2}{|c|}{$\mathrm{CHB}$} & \multicolumn{2}{|c|}{$\begin{array}{l}\mathrm{CHB}+\mathrm{LC} \\
\text { (non-HCC) }\end{array}$} & \multicolumn{2}{|l|}{$\mathrm{HCC}$} & \multirow{2}{*}{$\begin{array}{l}\text { HCC vs. CHB } \\
\text { OR }(95 \% \mathrm{Cl})\end{array}$} & \multirow[b]{2}{*}{$P^{*}$} & \multirow{2}{*}{$\begin{array}{l}\text { HCC vs. non-HCC } \\
\text { OR }(95 \% \text { Cl) }\end{array}$} & \multirow[b]{2}{*}{$P^{*}$} \\
\hline & $n$ & $\%$ & $\mathrm{n}$ & $\%$ & $n$ & $\%$ & & & & \\
\hline \multicolumn{11}{|l|}{ Codominant } \\
\hline $\mathrm{CC}$ & 76 & 42.2 & 117 & 44.8 & 86 & 52.8 & 1 & Ref & 1 & Ref \\
\hline$C A$ & 94 & 52.2 & 126 & 48.3 & 57 & 35 & $0.5(0.3-0.84)$ & 0.004 & $0.6(0.4-0.98)$ & 0.04 \\
\hline$A A$ & 10 & 5.6 & 18 & 6.9 & 20 & 12.3 & $1.84(0.7-4.8)$ & 0.206 & $1.4(0.7-3.0)$ & 0.189 \\
\hline \multicolumn{11}{|l|}{ Dominant } \\
\hline $\mathrm{CC}$ & 76 & 42.2 & 117 & 44.8 & 86 & 52.8 & 1 & Ref & 1 & Ref \\
\hline$C A+A A$ & 104 & 57.8 & 144 & 55.2 & 77 & 47.2 & $0.62(0.37-0.94)$ & 0.04 & $0.72(0.47-1.1)$ & 0.13 \\
\hline \multicolumn{11}{|l|}{ Recessive } \\
\hline$C C+C A$ & 170 & 94.4 & 243 & 93.1 & 143 & 87.7 & 1 & Ref & 1 & Ref \\
\hline AA & 10 & 5.6 & 18 & 6.9 & 20 & 12.3 & $2.56(1.01-6.48)$ & 0.04 & $1.74(0.8-3.65)$ & 0.14 \\
\hline \multicolumn{11}{|c|}{ Overdominant } \\
\hline$C C+A A$ & 86 & 47.8 & 135 & 51.7 & 106 & 65 & 1 & Ref & 1 & Ref \\
\hline$C A$ & 94 & 52.2 & 126 & 48.3 & 57 & 35 & $0.46(0.27-0.76)$ & 0.0023 & $0.6(0.38-0.90)$ & 0.017 \\
\hline
\end{tabular}

CHB Chronic hepatitis B, LC Liver cirrhosis, HCC Hepatocellular carcinoma; Non-HCC, CHB + LC; $\mathrm{n}=$ number of chromosomes; OR adjusted Odd Ratio; ORs and $P$ values were calculated by using binary logistic regression model adjusted for age and gender. ( $\left.{ }^{*}\right)$ Logistic regression model adjusted for age and gender. Bold values present the statistical significance

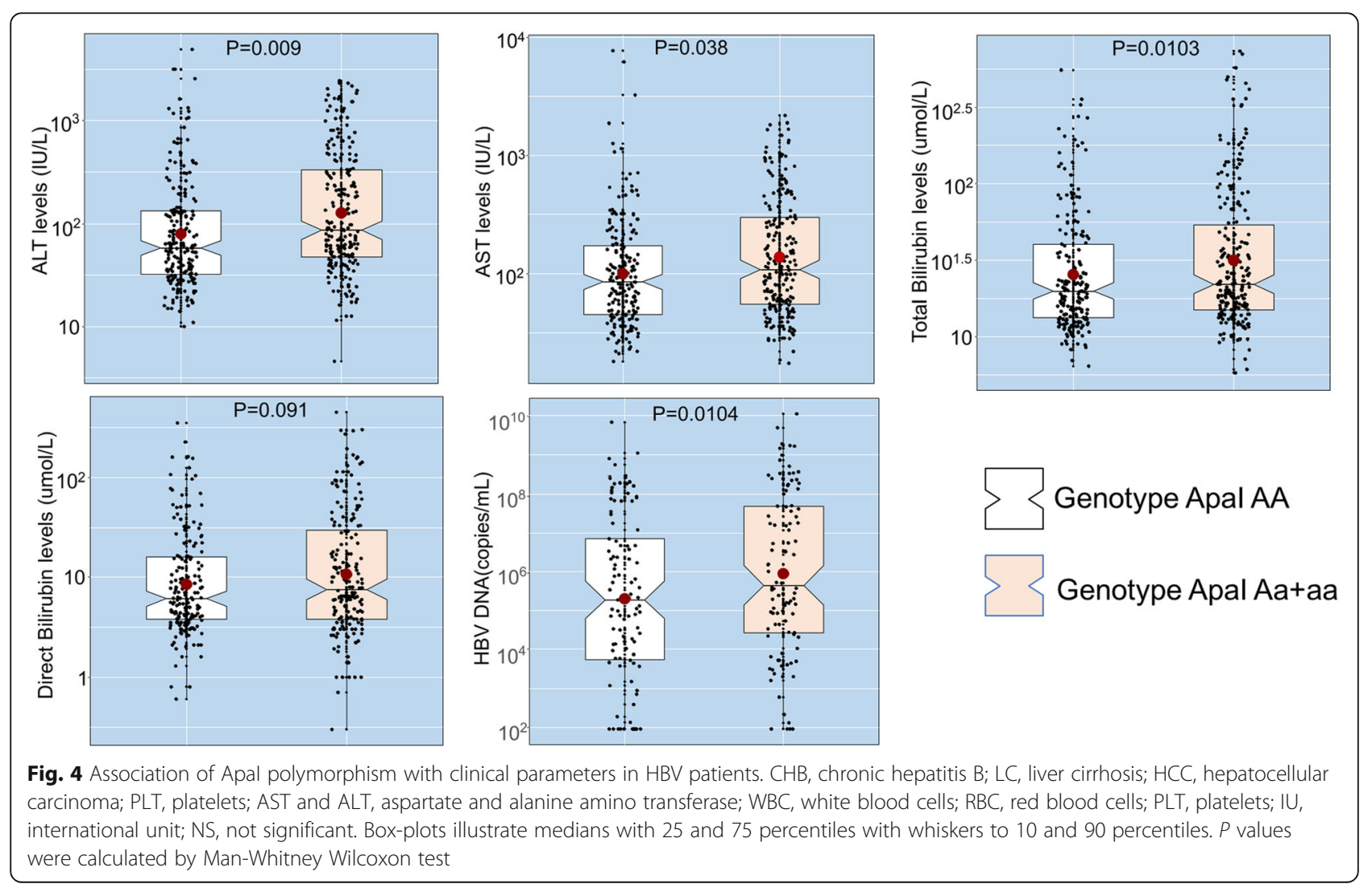



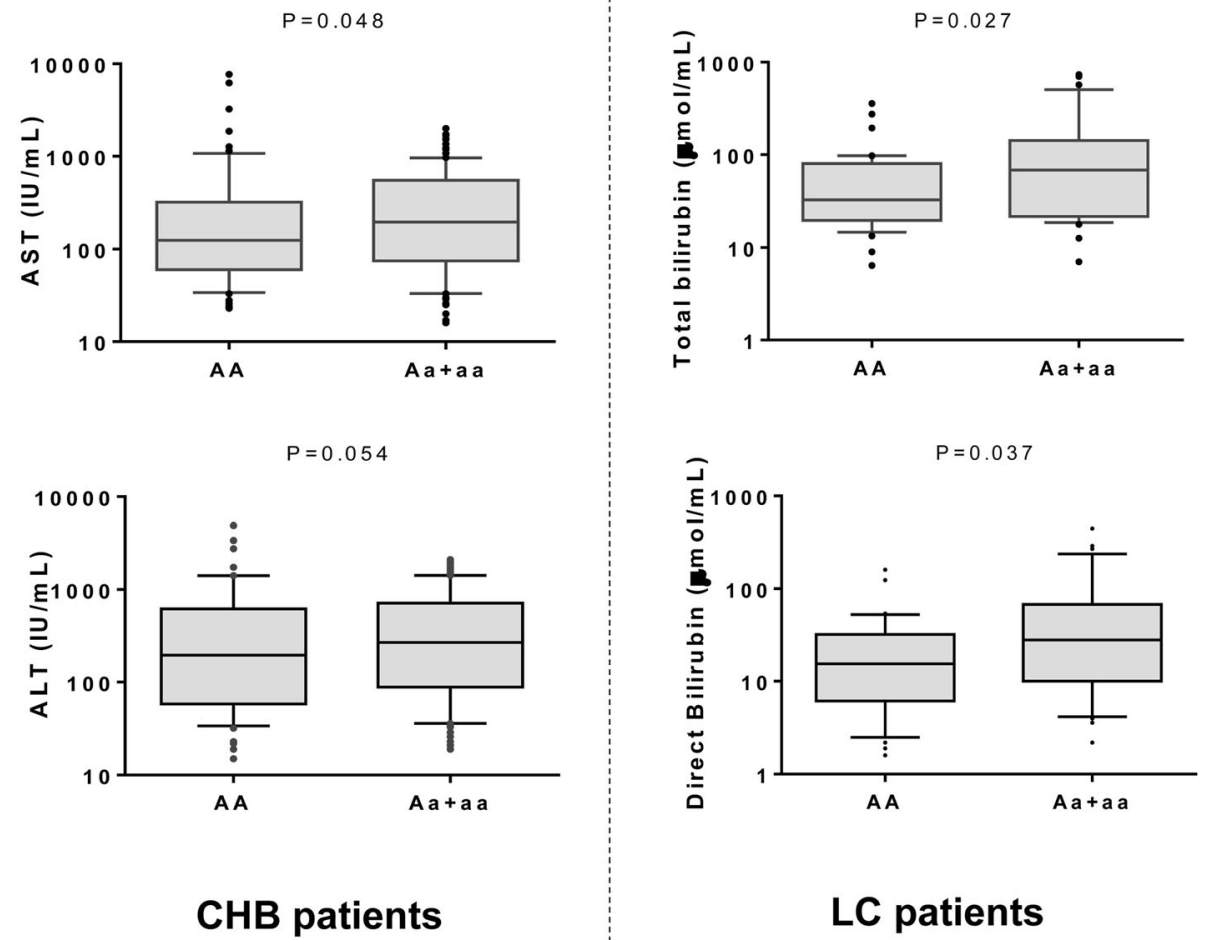

Fig. 5 Distribution of liver enzymes and bilirubin levels in CHB and LC patients. CHB, chronic hepatitis B; LC, liver cirrhosis; AST and ALT, aspartate and alanine amino transferase; IU, international unit. Box-plots illustrate medians with 25 and 75 percentiles with whiskers to 10 and 90 percentiles. $P$ values were calculated by Man-Whitney Wilcoxon test

mechanisms in several human diseases, including viral hepatitis $[6,11,21-25]$. We investigated the functional role of the four common VDR SNPs TaqI (rs731236) FokI (rs2228570), ApaI (rs7975232) and BsmI (rs1544410) in Vietnamese HBV-infected patients and observed a significant association between ApaI variability and clinical presentation and progression of HBV-related liver disease. The major and minor allele frequencies observed in this study were compared to available data in the 1000 genomes project. The allele frequencies were ApaI [rs7975232: Major allele $\mathrm{C}=0.7424$; Minor allele $\mathrm{A}=$ 0.2576]; FokI [rs2228570: Major allele G=0.5859; Minor allele $\mathrm{A}=0.4141$; Taq1 [rs731236: Major allele $\mathrm{T}=$ 0.9596; Minor allele $C=0.0404$ ] and for BsmI [rs1544410 Major allele $\mathrm{C}=0.9596$; Minor allele $\mathrm{T}=0.0404 \mathrm{]}$. The observed minor allele frequencies from this study corroborated well with the available data. Kinh ethnicity is a major ethnic population ( $>87 \% \sim 77$ million) in Vietnam. Based on mtDNA data, all Vietnamese carry South East Asian haplotypes, which show a limited geographic and ethnic stratification [35], therefore no population substructure is foreseen.

Several studies have investigated the biological functions of the four $V D R$ variants FokI (exon 2), BsmI (intron 8), ApaI (intron 8) and TaqI (exon 9) and their correlation with HBV infection [27-34]. However, the relationship between distinct $V D R$ variants and $\mathrm{HBV}$ infection and liver disease progression has remained controversial. Regarding the association of these polymorphisms with the risk of HBV infection, a recent meta-analysis including 15 studies could not reveal any evidence of correlation between TaqI, ApaI and BsmI polymorphisms with $\mathrm{HBV}$ infection; correlations were only observed for the FokI polymorphism [25].

Five of the 15 studies in the above-mentioned metaanalysis have assessed the association of ApaI polymorphisms with $\mathrm{HBV}$ infection; however, no correlation was observed (CC vs. CA and AA). This finding corresponds to the results of our present study (Table 3 ). On the other hand, there is not much information available on the ApaI polymorphism and progression of HBV-related liver diseases. Two previous studies have shown that ApaI polymorphism did not show positive association with the risk and clinicopathological features of HCC $[33,36]$. To our knowledge, our present study is the first to show an independent association between the VDR ApaI AA genotype and an increased risk of HBV-related development of HCC with a significant OR of 2.56 when 
comparing the $\mathrm{HCC}$ with the $\mathrm{CHB}$ group. An association of the ApaI CC genotype with the development of HCC among chronic hepatitis $\mathrm{C}$ patients has previously been demonstrated [37]. Allele ApaI C appears to contribute to a decreased susceptibility to $\mathrm{HCV}$ infection in a high-risk Chinese population [38]. A recent study has shown that the ApaI polymorphism was associated with the severity of liver cirrhosis caused by various etiologies [39].

Among numerous polymorphisms in the VDR gene, the FokI polymorphism is of great importance, as this missense variant causes a change of the start codon ATG to ACG, resulting in a modification of the VDR protein by three amino acids [40]. The modified protein, encoded by the FokI $G$ allele, binds more efficiently to vitamin $\mathrm{D}$ than does the longer version coded by the $\mathrm{A}$ allele $[26,40]$. It was suggested that the change in the VDR structure may alter the biological function of VDRvitamin $\mathrm{D}$ transcriptional signaling and may contribute to carcinogenesis, autoimmunity and susceptibility to infectious diseases, including viral hepatitis [34, 41]. As shown in the above-mentioned meta-analysis, eight studies including a total of 2516 cases, 1088 controls were subjected to the evaluation of the role of the FokI polymorphism in HBV infection. The FokI polymorphism was significantly associated with HBV infection in a codominant model [25].

Three other studies have investigated possible association of the FokI polymorphism with liver cancer and have suggested that the FokI polymorphisms might be used as a molecular marker to predict the risk and to evaluate the disease severity of HCC in HBV-infected patients $[33,34,36]$. Triantos et al. reported that the occurrence of the GG genotype was also an independent prognostic marker of survival, providing a possible protective role in LC patients [39]. Other studies have been conducted to investigate the potential role of the FokI variant in response to treatment with pegylated interferon in chronic hepatitis B and chronic hepatitis C [42, 43]. These studies have shown that the FokI polymorphism was an independent factor predicting success of PEG-IFN treatment response in HBV- or HCV-infected patients. Although these studies demonstrated the potential role of FokI variability in HBV infection and progression of liver diseases as well as response to antiviral treatment, our study could not confirm any correlation between the FokI polymorphism with either susceptibility to HBV infection or progression of HBV related-liver diseases.

The TaqI polymorphism has widely been studied in several malignant diseases such as breast cancer, prostate cancer, skin cancer, colorectal cancer, liver cancer and other malignancies [41, 44]. However, any effects of this variant on the development of cancer remain inconclusive. For instance, two meta-analyses have assessed the association of the TaqI polymorphism with the development of colorectal cancer, yielding inconsistent results $[45,46]$. While Serrano et al. reported that the genotype $\mathrm{CC}$ increases the risk of colorectal cancer by $43 \%$, but not for other malignancies [45], Sheng et al. concluded that no association between this genotype and susceptibility to colorectal cancer exists [46]. With regard to the association of the TaqI polymorphism with liver cancer, our study clearly confirms other studies, showing no significant association between the TaqI polymorphism and liver disease progression as well as development of HCC in both HBV and $\mathrm{HCV}$ infections [33, 37, 47].

Data on BSMI polymorphisms in HBV infection are scanty. Only three studies on associations of the BSMI polymorphism with HBV infection have been published to date $[33,48,49]$. These studies were included in the meta-analysis [25] and showed that BsmI was not a reliable indicator for the risk of HBV infection. In line with these studies, we did not find any association between $V D R$ polymorphisms and HBV infection, as well as progression of liver disease. Unlike the FokI variant, TaqI and BsmI variability does not influence the function of VDR expression [48]. This may explain why TaqI and BsmI polymorphisms were not associated with either HBV infection or disease progression in most studies conducted so far.

Vitamin D levels and liver disease progression and the response to antiviral therapy in $\mathrm{HBV}$ and $\mathrm{HCV}$ patients have previously been described [49]. Our previous study has shown that vitamin $\mathrm{D}$ levels decreased according to the progression of HBV-related liver disease [7]. One limitation of the study is that Vitamin D levels was measured only in fewer healthy controls compared to a large group of HBV patients. In the present study, we did not find any association of VDR polymorphisms with vitamin D levels in HBV-infected patients. Nevertheless, the correlation between VDR polymorphisms and vitamin D serum levels is not yet well established or this association is weak only. The influences of VDR polymorphisms on the course as well as the pathogenesis of HBV-related liver diseases remain still controversial and need to be explored further.

\section{Conclusions}

In this study, we examined the association of VDR polymorphisms TaqI, FokI, ApaI, and BsmI with HBV infection risk and with the progression of HBV-related liver diseases. Although there was no association between VDR polymorphisms with HBV infection risk, the ApaI polymorphism might be a genetic factor associated with the clinical outcome and disease progression in Vietnamese $\mathrm{HBV}$ infected patients. 


\section{Abbreviations}

AFP: Alpha-fetoprotein; ARMS: Amplification-refractory mutation system; AST and ALT: Aspartate and alanine amino transferase; CHB: Chronic hepatitis B; HBsAg: Hepatitis B surface antigen; HBV: Hepatitis B virus; HC: Healthy control; HCC: Hepatocellular carcinoma; LC: Liver cirrhosis; PLT: Platelets; SNP: Single nucleotide polymorphism; VDR: Vitamin D receptor

\section{Acknowledgements}

We would like to thank all the study subjects and blood donors for their participation and extend our thanks to colleagues for the help of sample collection.

\section{Authors' contributions}

LHS, NK designed the studies. NXH, MTB, DPG, NK, MHB, NTT, NLT, DTA collected the data and clinical samples. DPG, NTT, NK designed primers and experiments. NK, DPG MTB and NXH conducted the experiments. NXH analyzed the data and wrote the manuscript. LHS, TPV, NTT, NLT, DPG, NK and CGM revised the manuscript. All authors read and approved the manuscript.

\section{Funding}

We acknowledge the internal support from 108 Military Central Hospital, Hanoi. The funder has no role in study design, data collection and analysis, decision to publish, and/or preparation of the manuscript. TPV acknowledges DAAD-PAGEL (57140033) for student fellowship.

\section{Availability of data and materials}

All data generated or analysed during this study are included in this published article. Additional data are however available from the authors upon reasonable request.

\section{Ethics approval and consent to participate}

This study was performed in accordance with the Declaration of Helsinki and has been approved by an independent ethics committee. Informed written consent was obtained at the time of sampling from all participants. The study was approved by the Institutional Review Board and the Ethics committee of the 108 Military Central Hospital, Hanoi, Vietnam (108MCHVDR-01082011) and by the Ethics committee of the University of Tübingen (206/2012B02)

\section{Consent for publication}

Not Applicable.

\section{Competing interests}

The authors declare that they have no competing interests.

\section{Author details}

'Institute of Clinical Infectious Diseases, 108 Institute of Clinical Medical and Pharmaceutical Sciences, 108 Military Central Hospital, Tran Hung Dao Street N1, Hai Ba Trung District, Hanoi, Vietnam. ${ }^{2}$ Faculty of Tropical and Infectious Diseases, 108 Institute of Clinical Medical and Pharmaceutical Sciences, Hanoi, Vietnam. ${ }^{3}$ Institute of Tropical Medicine, University of Tübingen, Tübingen, Germany. ${ }^{4}$ Vietnamese-German Center for Medical Research (VG-CARE), Hanoi, Vietnam. ${ }^{5}$ Department of Infectious Diseases, Duc Giang Hospital, Hanoi, Vietnam. ${ }^{6}$ Department of Molecular Biology, 108 Institute of Clinical Medical and Pharmaceutical Sciences, Hanoi, Vietnam. ${ }^{7}$ Department of Gastroenterology, 108 Institute of Clinical Medical and Pharmaceutical Sciences, Hanoi, Vietnam. ${ }^{8}$ Department of Pathophysiology, Vietnam Military Medical University, Hanoi, Vietnam. ${ }^{9}$ Department of Infectious Diseases, 103 Military Hospital, Hanoi, Vietnam. ${ }^{10}$ Duy Tan University, Da Nang, Vietnam.

Received: 22 February 2019 Accepted: 3 October 2019

Published online: 21 December 2019

\section{References}

1. Trepo C, Chan HL, Lok A. Hepatitis B virus infection. Lancet. 2014;384(9959): 2053-63.

2. Nguyen VT. Hepatitis B infection in Vietnam: current issues and future challenges. Asia Pac J Public Health. 2012;24(2):361-73.

3. Autier P, Boniol M, Pizot C, Mullie P. Vitamin D status and ill health: a systematic review. Lancet Diabetes Endocrinol. 2014;2(1):76-89.
4. Holick MF, Chen TC. Vitamin D deficiency: a worldwide problem with health consequences. Am J Clin Nutr. 2008;87(4):1080S-6S.

5. Ali MM, Vaidya V. Vitamin D and cancer. J Cancer Res Ther. 2007;3(4):225-30.

6. Plum LA, Deluca HF. Vitamin D, disease and therapeutic opportunities. Nat Rev Drug Discov. 2010;9(12):941-55.

7. Hoan NX, Khuyen N, Binh MT, Giang DP, Van Tong H, Hoan PQ, Trung NT, Anh DT, Toan NL, Meyer CG, et al. Association of vitamin D deficiency with hepatitis B virus - related liver diseases. BMC Infect Dis. 2016;16(1):507.

8. Zhao XY, Li J, Wang JH, Habib S, Wei W, Sun SJ, Strobel HW, Jia JD. Vitamin $D$ serum level is associated with Child-Pugh score and metabolic enzyme imbalances, but not viral load in chronic hepatitis B patients. Medicine (Baltimore). 2016;95(27):e3926.

9. Farnik H, Bojunga J, Berger A, Allwinn R, Waidmann O, Kronenberger B, Keppler OT, Zeuzem S, Sarrazin C, Lange CM. Low vitamin D serum concentration is associated with high levels of hepatitis $B$ virus replication in chronically infected patients. Hepatology. 2013;58(4):1270-6.

10. Yu R, Tan D, Ning Q, Niu J, Bai X, Chen S, Cheng J, Yu Y, Wang H, Xu M, et al. Association of baseline vitamin $D$ level with genetic determinants and virologic response in patients with chronic hepatitis B. Hepatol Res. 2018; 48(3):E213-21.

11. Petta S, Camma C, Scazzone C, Tripodo C, Di Marco V, Bono A, Cabibi D, Licata G, Porcasi R, Marchesini G, et al. Low vitamin D serum level is related to severe fibrosis and low responsiveness to interferon-based therapy in genotype 1 chronic hepatitis C. Hepatology. 2010;51(4):1158-67.

12. Terrier B, Carrat F, Geri G, Pol S, Piroth L, Halfon P, Poynard T, Souberbielle JC, Cacoub P. Low 25-OH vitamin D serum levels correlate with severe fibrosis in HIV-HCV co-infected patients with chronic hepatitis. J Hepatol. 2011;55(4):756-61.

13. Garcia-Alvarez M, Pineda-Tenor D, Jimenez-Sousa MA, Fernandez-Rodriguez A, Guzman-Fulgencio M, Resino S. Relationship of vitamin D status with advanced liver fibrosis and response to hepatitis C virus therapy: a metaanalysis. Hepatology. 2014;60(5):1541-50.

14. Deluca HF, Cantorna MT. Vitamin D: its role and uses in immunology. FASEB J. 2001;15(14):2579-85.

15. Aranow C. Vitamin D and the immune system. J Investig Med. 2011;59(6): 881-6.

16. Cantorna MT, Zhu Y, Froicu M, Wittke A. Vitamin D status, 1,25dihydroxyvitamin D3, and the immune system. Am J Clin Nutr. 2004;80(6 Suppl):1717S-20S.

17. Kongsbak M, Levring TB, Geisler C, von Essen MR. The vitamin d receptor and T cell function. Front Immunol. 2013;4:148.

18. Kan M, Shi EG, McKeehan WL. Identification and assay of fibroblast growth factor receptors. Methods Enzymol. 1991;198:158-71.

19. Baeke F, Takiishi T, Korf H, Gysemans C, Mathieu C. Vitamin D: modulator of the immune system. Curr Opin Pharmacol. 2010;10(4):482-96.

20. Norman AW. From vitamin D to hormone D: fundamentals of the vitamin D endocrine system essential for good health. Am J Clin Nutr. 2008;88(2):491S-9S.

21. Wactawski-Wende J, Kotchen JM, Anderson GL, Assaf AR, Brunner RL, O'Sullivan MJ, Margolis KL, Ockene JK, Phillips L, Pottern L, et al. Calcium plus vitamin D supplementation and the risk of colorectal cancer. N Engl J Med. 2006;354(7):684-96.

22. Targher G, Bertolini L, Scala L, Cigolini M, Zenari L, Falezza G, Arcaro G. Associations between serum 25-hydroxyvitamin D3 concentrations and liver histology in patients with non-alcoholic fatty liver disease. Nutr Metab Cardiovasc Dis. 2007;17(7):517-24.

23. Raimondi S, Pasquali E, Gnagnarella P, Serrano D, Disalvatore D, Johansson HA, Gandini S. Bsml polymorphism of vitamin D receptor gene and cancer risk: a comprehensive meta-analysis. Mutat Res. 2014;769:17-34.

24. Gao W, Wang R, Wang X, Wu H, Wang Y, Lu X, Li L, Zheng J, Li W. Vitamin $D$ serum levels and receptor genetic polymorphisms are associated with hepatitis B virus and HIV infections and IFN-lambda levels. Biomark Med. 2017;11(9):733-40.

25. He Q, Huang Y, Zhang L, Yan Y, Liu J, Song X, Chen W. Association between vitamin $D$ receptor polymorphisms and hepatitis $B$ virus infection susceptibility: A meta-analysis study. Gene. 2018;645:105-12.

26. Miyamoto K, Kesterson RA, Yamamoto H, Taketani Y, Nishiwaki E, Tatsumi S, Inoue Y, Morita K, Takeda E, Pike JW. Structural organization of the human vitamin D receptor chromosomal gene and its promoter. Mol Endocrinol. 1997;11(8):1165-79.

27. Li JH, Li HQ, Li Z, Liu Y, Gao JR, Zeng XJ, Gou CY, Zhu XL, Guo XH. Pan L et al: [Association of Taq I T/C and Fok I C/T polymorphisms of vitamin D 
receptor gene with outcome of hepatitis B virus infection]. Zhonghua $Y$ Xue Za Zhi. 2006;86(28):1952-6.

28. Li J, Dong PH, Jin YH, Lu MQ, Pan FF, Wang BS, Chen YP. The relationship between vitamin $\mathrm{D}$ receptor gene polymorphism and liver fibrosis. Zhejiang Med J. 2006;28:426-34

29. Zhu Q, Li N, Han Q, Li Z, Zhang G, Li F, Zhang P, Chen J, Lv Y, Liu Z. Singlenucleotide polymorphism at CYP27B1-1260, but not VDR Taq I, is possibly associated with persistent hepatitis B virus infection. Genet Test Mol Biomarkers. 2012;16(9):1115-21.

30. Arababadi MK, Pourfathollah AA, Jafarzadeh A, Hassanshahi G, Rezvani ME. Association of exon 9 but not intron 8 VDR polymorphisms with occult HBV infection in south-eastern Iranian patients. J Gastroenterol Hepatol. 2010; 25(1):90-3.

31. Chatzidaki V, Choumerianou D, Dimitriou H, Kouroumalis E, Galanakis E. Genetic variants associated with susceptibility to mother-to-child transmission of hepatitis B virus. Eur J Gastroenterol Hepatol. 2012;24(10):1185-90.

32. Karatayli SC, Ulger ZE, Ergul AA, Keskin O, Karatayli E, Albayrak R, Ozkan M, Idilman R, Yalcin K, Bozkaya H, et al. Tumour necrosis factor-alpha, interleukin-10, interferon-gamma and vitamin $D$ receptor gene polymorphisms in patients with chronic hepatitis delta. J Viral Hepat. 2014; 21(4):297-304.

33. Yao X, Zeng H, Zhang G, Zhou W, Yan Q, Dai L, Wang X. The associated ion between the VDR gene polymorphisms and susceptibility to hepatocellular carcinoma and the clinicopathological features in subjects infected with HBV. Biomed Res Int. 2013;2013:953974.

34. Peng Q, Yang S, Lao X, Li R, Chen Z, Wang J, Qin X, Li S. Association of single nucleotide polymorphisms in VDR and DBP genes with HBV-related hepatocellular carcinoma risk in a Chinese population. PLoS One. 2014;9(12): e116026.

35. Pischedda S, Barral-Arca R, Gomez-Carballa A, Pardo-Seco J, Catelli ML, Alvarez-Iglesias V, Cardenas JM, Nguyen ND, Ha HH, Le AT, et al. Phylogeographic and genome-wide investigations of Vietnam ethnic groups reveal signatures of complex historical demographic movements. Sci Rep. 2017;7(1):12630.

36. Mohammed AM, Hany S, Tarek S, Nesreen MO, Soad AM. Vitamin D Receptor Gene Polymorphisms as a Predictive Risk Factor for Hepatocellular Carcinoma Development and Severity in Chronic Hepatitis B. Int J Cancer Res. 2017;13(1):26-35.

37. Hung CH, Chiu YC, Hu TH, Chen CH, Lu SN, Huang CM, Wang JH, Lee CM. Significance of vitamin d receptor gene polymorphisms for risk of hepatocellular carcinoma in chronic hepatitis C. Transl Oncol. 2014;7(4):503-7.

38. Wu M, Yue M, Huang P, Zhang Y, Xie C, Yu R, Li J, Wang J. Vitamin D level and vitamin $\mathrm{D}$ receptor genetic variations contribute to $\mathrm{HCV}$ infection susceptibility and chronicity in a Chinese population. Infect Genet Evol. 2016:41:146-52

39. Triantos C, Aggeletopoulou I, Kalafateli M, Spantidea PI, Vourli G, Diamantopoulou G, Tapratzi D, Michalaki M, Manolakopoulos S, Gogos C, et al. Prognostic significance of vitamin D receptor (VDR) gene polymorphisms in liver cirrhosis. Sci Rep. 2018;8(1):14065.

40. Uitterlinden AG, Fang Y, Van Meurs JB, Pols HA, Van Leeuwen JP. Genetics and biology of vitamin D receptor polymorphisms. Gene. 2004;338(2):143-56.

41. Rai V, Abdo J, Agrawal S, Agrawal DK. Vitamin D Receptor Polymorphism and Cancer: An Update. Anticancer Res. 2017;37(8):3991-4003.

42. Mostafa-Hedeab G, Sabry D, Abdelaziz GM, Ewaiss M, Adli N, Fathy W. Influence of Vitamin D Receptor Gene Polymorphisms on Response to Pegylated Interferon in Chronic Hepatitis B Egyptian Patients. Rep Biochem Mol Biol. 2018;6(2):186-96.

43. Abdelsalam A, Rashed L, Salman T, Hammad L, Sabry D. Molecular assessment of vitamin $\mathrm{D}$ receptor polymorphism as a valid predictor to the response of interferon/ribavirin-based therapy in Egyptian patients with chronic hepatitis C. J Dig Dis. 2016;17(8):547-53.

44. Falleti E, Bitetto D, Fabris C, Cussigh A, Fontanini E, Fornasiere E, Fumolo E, Bignulin S, Cmet S, Minisini R, et al. Vitamin D receptor gene polymorphisms and hepatocellular carcinoma in alcoholic cirrhosis. World J Gastroenterol. 2010;16(24):3016-24.

45. Serrano D, Gnagnarella P, Raimondi S, Gandini S. Meta-analysis on vitamin D receptor and cancer risk: focus on the role of Taql, Apal, and Cdx2 polymorphisms. Eur J Cancer Prev. 2016;25(1):85-96.

46. Sheng S, Chen Y, Shen Z. Correlation between polymorphism of vitamin D receptor Taql and susceptibility to colorectal cancer: A meta-analysis. Medicine (Baltimore). 2017;96(26):e7242.
47. Huang YW, Liao YT, Chen W, Chen CL, Hu JT, Liu CJ, Lai MY, Chen PJ, Chen DS, Yang SS, et al. Vitamin D receptor gene polymorphisms and distinct clinical phenotypes of hepatitis B carriers in Taiwan. Genes Immun. 2010; 11(1):87-93.

48. Whitfield GK, Remus LS, Jurutka PW, Zitzer H, Oza AK, Dang HT, Haussler CA, Galligan MA, Thatcher ML, Encinas Dominguez C, et al. Functionally relevant polymorphisms in the human nuclear vitamin D receptor gene. Mol Cell Endocrinol. 2001;177(1-2):145-59.

49. Hoan NX, Tong HV, Song LH, Meyer CG, Velavan TP. Vitamin D deficiency and hepatitis viruses-associated liver diseases: A literature review. World J Gastroenterol. 2018;24(4):445-60.

\section{Publisher's Note}

Springer Nature remains neutral with regard to jurisdictional claims in published maps and institutional affiliations.
Ready to submit your research? Choose BMC and benefit from:

- fast, convenient online submission

- thorough peer review by experienced researchers in your field

- rapid publication on acceptance

- support for research data, including large and complex data types

- gold Open Access which fosters wider collaboration and increased citations

- maximum visibility for your research: over $100 \mathrm{M}$ website views per year

At BMC, research is always in progress.

Learn more biomedcentral.com/submissions 